\title{
ACADEMIC WORKLOADS: INPUTS TO INSTRUCTIONAL LEADERS' PRODUCTIVITY AND JOB SATISFACTION
}

\author{
Maica A. Talastas \\ Faculty, Taykin Elementary School
}

Article DOI: $\underline{\text { https://doi.org/10.36713/epra7446 }}$

DOI No: 10.36713/epra7446

\begin{abstract}
This study was conducted to determine the significant effect of academic workloads to productivity and job satisfaction of elementary teachers in selected schools in Liliw District, Laguna. It is important to value the teachers' productivity and job satisfaction because the researcher believed that these influences teachers' turnover and quality of teaching. The independent variables included the academic workloads of elementary teachers. On the other hand, teachers' productivity and job satisfaction are used as an indicator for dependent variables. It aimed to answer the questions such as the mean level of respondent's academic workloads in terms of: Teaching Load Allocation, Working Hours, Preparation Time, Coaching and Mentoring and Ancillary Function. Also, the mean level of instructional leaders' productivity in terms of Community services and linkages, Research, Professional Development and Awards and Recognition as well as the mean level of instructional leaders' job satisfaction in terms of Work Condition, Job Security, Salaries and Benefits, Working Environment; and Social Satisfaction. Presented the summary of findings, ancillary function had a significant effect to instructional leaders' productivity as to research and job satisfaction as to Job Security, Salaries and Benefits. Preparation time had a significant effect to teachers' job satisfaction as to work condition and social satisfaction. Ancillary function and preparation time had significant effect to teachers' productivity as to community services and linkages and professional development. Therefore, the null hypothesis that academic workloads have no significant effect on instructional leaders' productivity and job satisfaction among selected elementary schools in Liliw, Laguna at 0.05 level of significance was partially accepted. Based on the drawn conclusions resulted to the following recommendations: Rebalance the workload on a regular basis, it may be recommended that automating faculty workload to ensure faculties in institutions optimally spend their time and align with the interests of the institution to maximize efficiency and effectiveness in all areas of operations. Faculty workload management system can help administrators to determine how best to divide the work. Furthermore, creating an action plan based on evaluation scores to enable faculty members to attend workshops, courses and conferences that promote the development of skills for both teaching and research can also be an option for the Academic Workloads of teachers to be improved.
\end{abstract}

\section{INTRODUCTION}

In 2017, the Philippine Daily Inquirer recorded 190,530 school teachers in 50,000 public elementary and high schools all over the country catering 22.8 million students. These statistics is very crucial in the country whose mandate is providing free basic education to all Filipino children. In 2017, the teacher - student ratio is about 1:45 and 1:36 in the elementary and 1:32 and 1:26 in high school.

As a result of continues increase in teacher-students ratio, teachers' workloads related to teaching loads and other related school works continues to increase. In order to address all teaching-related tasks, the workforce often work long hours. The workloads of Filipino teachers are intensifying, their nonteaching roles are becoming 


\section{SJIF Impact Factor 2021: 8.013| ISI I.F.Value:1.241| Journal DOI: 10.36713/epra2016 ISSN: 2455-7838(Online) EPRA International Journal of Research and Development (IJRD) Volume: 6 | Issue: 7 | July 2021

significantly more extensive, and teachers are being asked to take on responsibilities for which they are not properly trained.

Nowadays, teachers are facing a number of changes in their job context. Sadly, many of which significantly affect their work lives. Teachers are working longer hours, they are assigned not only with teaching more students but also having more professional and administrative duties.

Among other reasons, the idea that teachers work minimal hours is misleading. Most teachers work far beyond the actual school day, and spend a large portion of their time planning lessons, grading papers, and communicating with parents.

Another working condition for teachers that may be under-recognized is the fact that teacher's "To Do" list is rarely complete. Whether preparing for a new lesson, or working to retain your students' interest in the middle of the school year, there is always something to do and file of work to be accomplished that may lessen the preparation time to provide the best education for the learners.

The researcher seeks to find out the relationship of academic work loads and their effect to instructional leaders' productivity and job satisfaction among public school elementary teachers in Liliw District. It is important to value the teachers productivity and job satisfaction because the researcher believes that these influences teachers' turnover and quality of teaching.

\section{RESEARCH METHODOLOGY}

The researcher made use of the descriptive survey research method. This method refers to the collection of data from members of the population in which direct contact is made by means of survey questionnaires and checklist.The descriptive method is preferred since it yields valid and reliable results for a manageable number of respondents and can be accomplished with limited resources. A survey instrument was used to obtain data from the randomly selected respondents. The process of descriptive survey research goes beyond mere gathering and tabulation of data. It involves an element of interpretation of the meaning or significance of what is being described.

Forty five (45) randomly selected public school elementary teachers from Liliw, Laguna were used as respondents in this study. The independent variables included the academic workloads of elementary teachers from Liliw, Laguna. On the other hand, teachers' productivity and job satisfaction are used as an indicator for dependent variables. This study focused on the academic workload in relation to instructional leaders' productivity and job satisfaction in Liliw District, Laguna

According to Ariola et.al. (2006) when it is not possible to study the entire population, a smaller sample was taken using a random sampling technique. Randomly selected elementary teachers from the District of Liliw, Laguna were used as respondents in the conduct of this research.

The instrument used in the study is a survey questionnaire-checklist. The questionnaire is a research-made instrument devised to determine the academic workloads and its effect to instructional leaders' productivity and job satisfaction in Liliw District, Laguna. The questionnaire used a five point likert scale to find out the mean level of teachers' academic workloads as well as the mean level of instructional leaders' productivity and job satisfaction.

In the questionnaire, a five point rating scale indicated below was used.

\begin{tabular}{|c|c|c|c|}
\hline Scale & $\begin{array}{c}\text { Numerical } \\
\text { Value }\end{array}$ & $\begin{array}{c}\text { Classroom Teaching Load } \\
\text { and Related School Works }\end{array}$ & $\begin{array}{c}\text { Teachers' } \\
\text { Productivity and } \\
\text { Job Satisfaction }\end{array}$ \\
\hline 5 & $4.20-5.0$ & Always & Outstanding \\
\hline 4 & $3.40-4.19$ & Often & Very satisfactory \\
\hline 3 & $2.60-3.39$ & Sometimes & Satisfactory \\
\hline 2 & $1.80-2.59$ & Seldom & Fair \\
\hline 1 & $1-1.79$ & Never & Poor \\
\hline
\end{tabular}

In the construction of questionnaire described above, an extensive review of various books, publications and internet sites were used. An initial draft of the research tool was prepared and presented to professors and panel members for comments and suggestions. Validation was done to assess the representation of the items with those of others dealing with same area of investigation. The assistance of the adviser relevant to the contents of the questionnaire was solicited. The final form of the questionnaire was reproduced and administered to respective respondents. 
The researcher sought permission from the Schools Division Superintendent, District Supervisor and Principals of the school respondent in Liliw District, Laguna to gather the needed data through letter of request for this study. Upon approval, a meeting was set to meet the respondents before the actual administration of the questionnaire in order to orient them relative to the purpose of the study. The respondents were oriented on how to accomplish the entire set of questionnaire. The distribution and retrieval of questionnaire was administered personally by the researcher through online platforms in order to follow-up vague responses made by the respondent for consistency check. The researcher explained fully the direction as well as the purpose of the study before allowing the respondents to answer the questionnaire. Later, the data were gathered, given appropriate statistical treatment, which will be analyzed and interpreted.

\section{Statistical Treatment}

The responses were tabulated as basis for statistical treatment of the data. In order to analyze and interpret the data gathered, the following statistical tools were utilized in the study. Weighted mean, standard deviation and pearson- $\mathrm{R}$ were used to in the conduct of this research.

\section{RESULTS AND FINDINGS}

Table 1. Mean Level of Respondent's Academic Workloads In terms of Teaching Load Allocation

\begin{tabular}{lcc}
\hline \multicolumn{1}{c}{ STATEMENT } & Mean & Remarks \\
\hline $\begin{array}{l}\text { 1. Teach six hours a day as intended } \\
\text { 2. Am given three to four teaching preparation this school }\end{array}$ & 4.49 & Always \\
$\begin{array}{l}\text { year. } \\
\begin{array}{l}\text { 3. Remain in the present grade level for at least three years for } \\
\text { mastery. }\end{array}\end{array}$ & 4.07 & Often \\
$\begin{array}{l}\text { 4. Teach subjects in my field of specialization. } \\
\begin{array}{l}\text { 5. Have agreed to reduce teaching loads when assigned to other } \\
\text { ancillary functions. }\end{array}\end{array}$ & 3.87 & Often \\
$\begin{array}{l}\text { 6. Additional workloads are disseminated equally to teachers. } \\
\text { 7. Workloads/ancillary functions are designated properly to }\end{array}$ & 3.73 & Often \\
teachers with credentials in relation to assigned function. & 3.93 & Often \\
\hline
\end{tabular}

\begin{tabular}{|c|c|c|c|c|}
\hline \multicolumn{3}{|c|}{ Grand Mean } & 3.92 & Often \\
\hline \multicolumn{3}{|c|}{ Interpretation } & \multicolumn{2}{|r|}{ To a Great Extent } \\
\hline $\begin{array}{l}\text { Legend: } \\
\text { Scale }\end{array}$ & Ranoe & Remarks & \multicolumn{2}{|l|}{ Interpretation } \\
\hline 5 & $4.20-5.00$ & Always & \multicolumn{2}{|l|}{ To a Very Great Extent } \\
\hline 2 & $3.40-4.19$ & Often & \multicolumn{2}{|l|}{ To a Great Extent } \\
\hline 3 & $2.60-3.39$ & Sometimes & \multicolumn{2}{|l|}{ Moderate Extent } \\
\hline 2 & $1.80-2.59$ & Seldom & \multicolumn{2}{|l|}{ To a Low Extent } \\
\hline 1 & $1.0-1.79$ & Never & \multicolumn{2}{|l|}{ To a Very Low Extent } \\
\hline
\end{tabular}

The result shows that the teaching load allocation was to a great extent supported by the weighted mean of 3.92. This means that the respondents were perceived that the teaching load assigned to them was distributed equally according to their field of specialization.

It was evident in the table that the respondents always teach six hours a day which was supported by the obtained highest weighted mean of 4.49. However, they have agreed to reduce teaching loads when assigned to other ancillary functions, often as implied lowest weighted mean of 3.29. This meant that the teaching load given to the respondents enables them to have adequate time of teaching as well as performing other functions assigned to them. 
According to Ou, X. (2016), teaching load distribution, that is, which education staff teaches which subject, is a critical duty that is supported out in entirely teaching and teaching/research organizations. Teaching load allocation has been well known as a main causal factor to the teaching excellence.

In Table 2, the result shows that the working hours was to a great extent supported by the weighted mean of 4.00. This means that the respondents agreed that the working hours they commit to teach and share knowledge to students are apparent.

It was evident in the table that the respondents always have an hour daily to enjoy their lunch break which was supported by the obtained highest weighted mean of 4.76. However, they partly accepted that work may be performed beyond eight hours a day provided that the employee is paid for the overtime work as implied with a lowest weighted mean of 3.22. This meant that the working hours given to the respondents enables them to have adequate time of teaching as well as performing other functions assigned to them.

Table 2. Mean Level of Respondent's Academic Workloads In terms of Working Hours

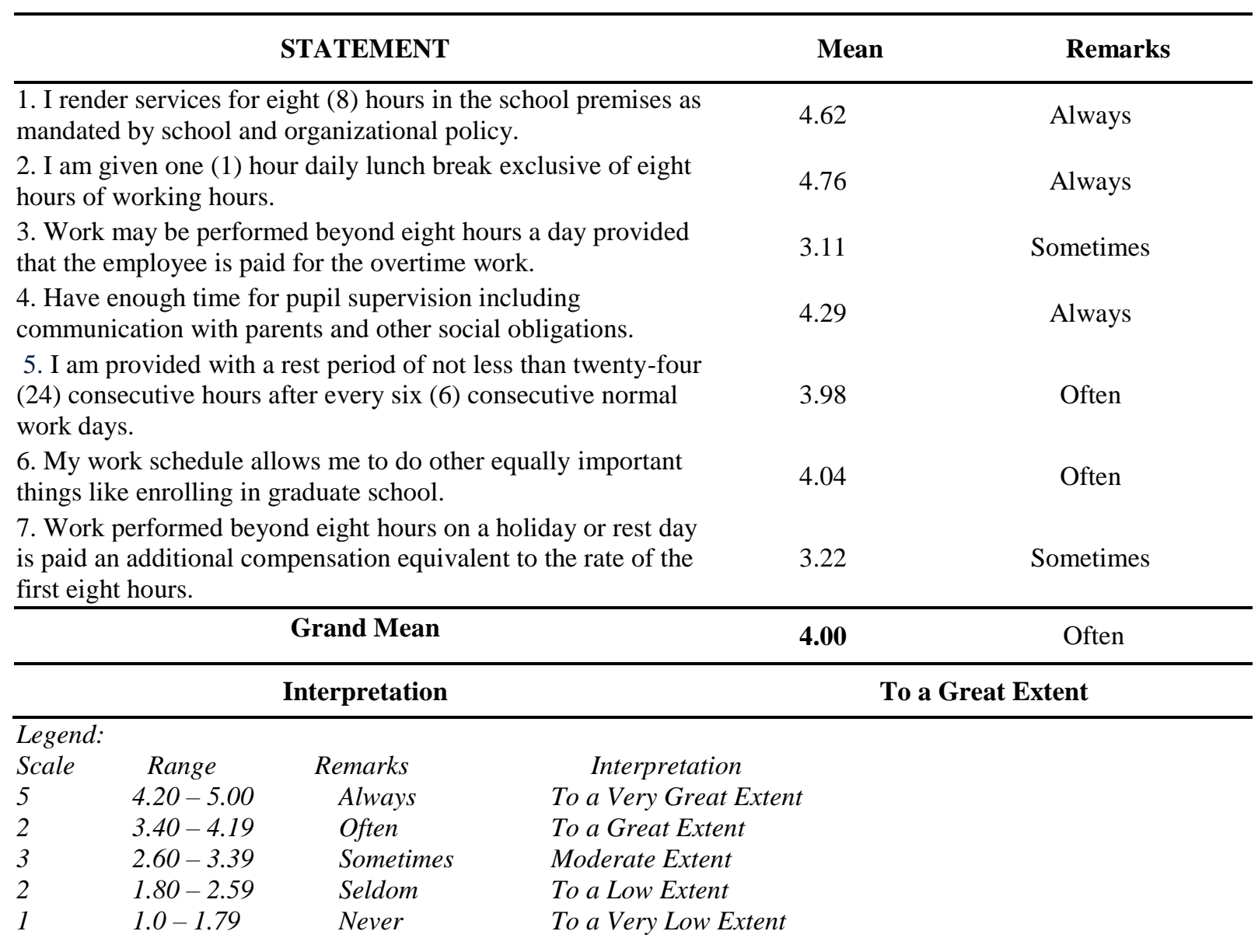


Table 3. Mean Level of Respondent's Academic Workloads In terms of Preparation Time

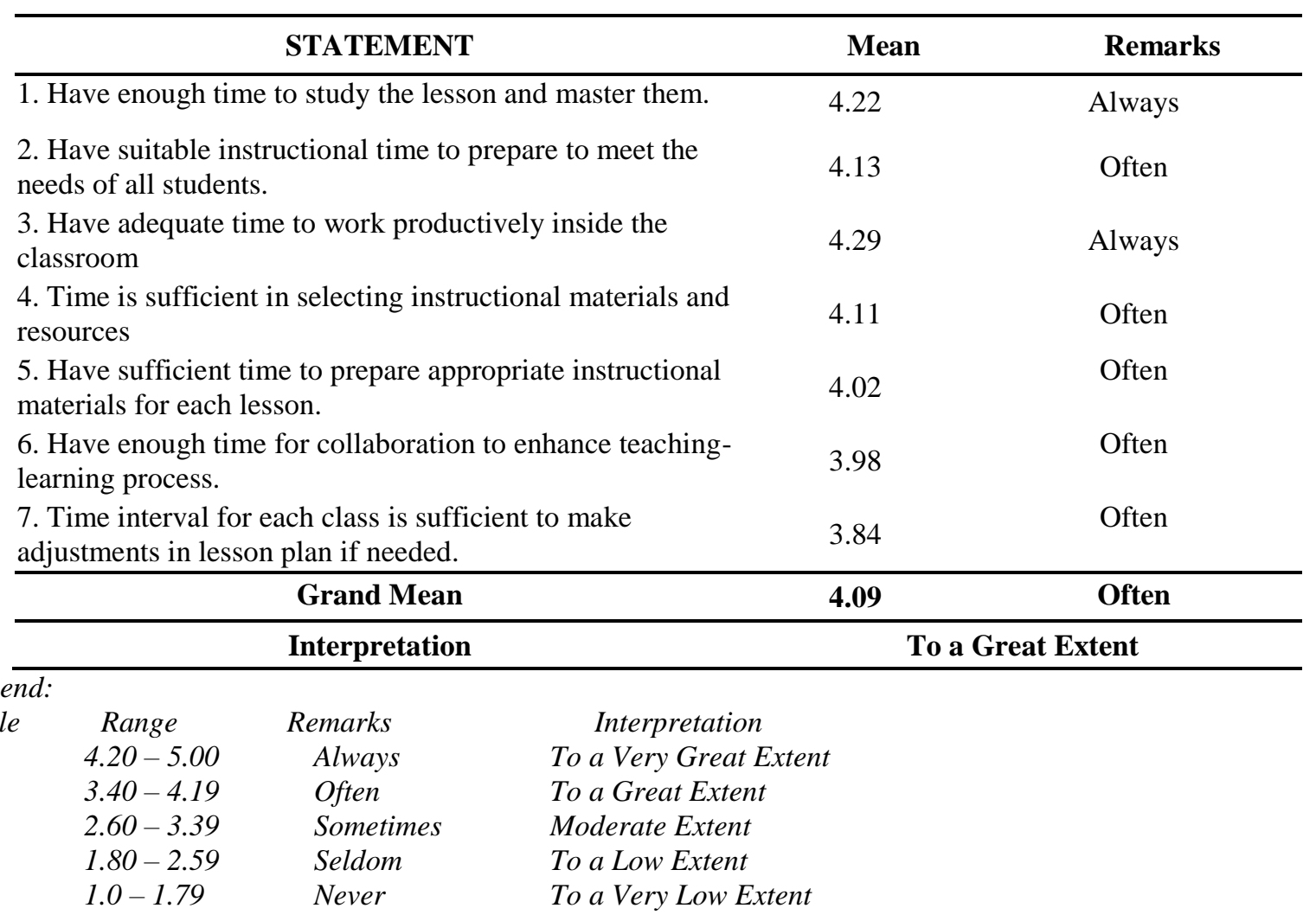

The result shows that the preparation time was to a great extent supported by the weighted mean of 4.09. This means that the respondents agreed that the preparation time they have received are just enough for them to supply enough knowledge that the students need.

It was evident in the table that the respondents have adequate time to work productively inside the classroom which was supported by the obtained highest weighted mean of 4.29. However, they partly accepted time interval for each class is sufficient to make adjustments in lesson plan if needed as implied with a lowest weighted mean of 3.84. This meant that the preparation time provided for the teachers is just enough for them.

Meador, D. (2019) stated that lack of time in planning or poor time management has been identified as a major cause of stress. He identified too much paperwork, lack of time to spend with individual pupils and demands on after-school time as major causes of stress for teachers.

Table 4. Mean Level of Respondent's Academic Workloads In terms of Coaching and Mentoring

\begin{tabular}{lll}
\hline \multicolumn{1}{c}{ STATEMENT } & Mean & Remarks \\
\hline $\begin{array}{l}\text { 1. Guide the students' performance by providing additional } \\
\text { activities for improvement. }\end{array}$ & 4.22 & Always \\
$\begin{array}{l}\text { 2. Give special trainings and classes to students with potentials } \\
\text { to excel. }\end{array}$ & 3.98 & Often \\
$\begin{array}{l}\text { 3. Shift into alternative approaches to address the needs of the } \\
\text { students }\end{array}$ & 4.16 & Often \\
$\begin{array}{l}\text { 4. Help young or less experienced students and co-workers. } \\
\text { (16 }\end{array}$ & 4.18 & Often
\end{tabular}


5. Facilitate SLAC sessions to teachers and co-workers to promote and enhance skills related to teaching-learning process. 6. Guide the students' behavior by means of monitoring for improvement.

7. Enhancement classes are conducted to improve students' knowledge and potentials.
3.89
Often
Always
4.18
Often

\begin{tabular}{lcccc}
\hline & \multicolumn{2}{c}{ Grand Mean } & $\mathbf{4 . 1 3}$ & Often \\
\hline & & Interpretation & & To a Great Extent \\
\hline Legend: & Range & Remarks & \multicolumn{1}{c}{ Interpretation } & \\
Scale & $4.20-5.00$ & Always & To a Very Great Extent & \\
5 & $3.40-4.19$ & Often & To a Great Extent & \\
2 & $2.60-3.39$ & Sometimes & Moderate Extent & \\
3 & $1.80-2.59$ & Seldom & To a Low Extent & \\
2 & $1.0-1.79$ & Never & To a Very Low Extent & \\
1 & & &
\end{tabular}

The result shows that coaching and mentoring was to a great extent supported by the weighted mean of 4.13. This means that the respondents agreed that the coaching and mentoring they have received are just enough for them to supply enough knowledge that the students need.

In Table 4, it was evident in the table that the respondents guide the students' behavior by means of monitoring for improvement which was supported by the obtained highest weighted mean of 4.29. However, they partly accepted that facilitating SLAC sessions to teachers and co-workers to promote and enhance skills related to teaching-learning process as implied with a lowest weighted mean of 3.89. This meant that the coaching and mentoring provided for the teachers is palpable.

Olivero, Bane, and Kopelman (2017), state that international studies and research literature about the use of coaching and mentoring approaches to support the development of leaders and teachers, is extensive.

The result shows that the ancillary function was to a great extent supported by the weighted mean of 3.85 . This means that the respondents agreed that the ancillary function they have received are just enough for them to support the main work of the institution.

It was evident in the table that the respondents are given supporting tasks in addition to teaching load like event and sports coaching which was supported by the obtained highest weighted mean of 4.09 . However, they have given the task to monitor and attend to the needs of teachers on the same grade level as implied with a lowest weighted mean of 3.42. This meant that the ancillary function provided for the teachers is profound.

Table 5. Mean Level of Respondent's Academic Workloads In terms of In terms of Ancillary Function

\begin{tabular}{lll}
\hline \multicolumn{1}{c}{ STATEMENT } & Mean & Remarks \\
\hline $\begin{array}{l}\text { 1. Am given supporting tasks in addition to teaching load like } \\
\text { event and sports coaching. }\end{array}$ & 4.09 & Often \\
$\begin{array}{l}\text { 2. Ask to give additional support to student's activities as club } \\
\text { advisers }\end{array}$ & 3.98 & Often \\
$\begin{array}{l}\text { 3. Act as school counsellor to provide the first point of contact } \\
\text { for students, parents and community groups through case } \\
\text { management. }\end{array}$ & 3.67 & Often \\
$\begin{array}{l}\text { 4. Am given the task to monitor and attend to the needs of } \\
\text { teachers on the same grade level. }\end{array}$ & 3.42 & Often \\
5. Am assigned to monitor student nutrition, deworm and assist & 4.04 & Often
\end{tabular}


student with health condition

6. Have additional workload to assist students that needs medical attention and supervision,

$3.69 \quad$ Often

7. Maintain and monitor books and other resources of the school.

\begin{tabular}{lcccc}
\hline & Grand Mean & & Often \\
\hline & & & $\mathbf{3 . 8 5}$ & To a Great Extent \\
\hline Legend: & & & \\
Scale & Range & Remarks & \multicolumn{1}{c}{ Interpretation } & \\
5 & $4.20-5.00$ & Always & To a Very Great Extent & \\
2 & $3.40-4.19$ & Often & To a Great Extent & \\
3 & $2.60-3.39$ & Sometimes & Moderate Extent & \\
2 & $1.80-2.59$ & Seldom & To a Low Extent & \\
1 & $1.0-1.79$ & Never & To a Very Low Extent &
\end{tabular}

Don, Puteh, Nasir, Ashaari, \& Kawangit (2016) also stated that numerous ancillary roles were perceived by the teachers as a factor supporting their well-being. At the emotional level, mingling teaching with additional subsidiary role seemed to support teachers in stepping back from circumstances encountered at school and keeping problems in perspective.

\section{Instructional Leaders' Productivity}

Instructional Leaders' Productivity was determined by the weighted mean and described in terms of community services and linkages, research, professional development and awards and recognition and achievement.

\section{Table 6. The Mean Level Of Instructional Leaders' Productivity In terms of Community Services and} Linkages

\begin{tabular}{lll}
\hline \multicolumn{1}{c}{ STATEMENT } & Mean & Remarks \\
$\begin{array}{l}\text { 1. Teachers and program beneficiaries show willingness to } \\
\text { participate in extension activities. }\end{array}$ & 4.02 & Very Satisfactory \\
$\begin{array}{l}\text { 2. Programs for community services are planned and } \\
\text { implemented regularly by the school. }\end{array}$ & 3.89 & Very Satisfactory \\
$\begin{array}{l}\text { 3. Community services are performed by teaching staff and } \\
\text { personnel. }\end{array}$ & 3.89 & Very Satisfactory \\
$\begin{array}{l}\text { 4. The school provides awareness on the importance of } \\
\text { community services. }\end{array}$ & 4.20 & Very Satisfactory \\
$\begin{array}{l}\text { 5. The school acknowledge the influence of community services } \\
\text { to promote positive school culture. }\end{array}$ & 4.24 & Outstanding \\
$\begin{array}{l}\text { 6. Teachers plan and do community services to help people } \\
\text { enhance and develop their lives in the communities. }\end{array}$ & 4.13 & Very Satisfactory \\
$\begin{array}{l}\text { 7. Teachers provide and perform skills development trainings } \\
\text { and life skills to form linkages to nearby communities. }\end{array}$ & 4.09 & Very Satisfactory \\
\hline \multicolumn{1}{c}{ Grand Mean } & $\mathbf{4 . 0 7}$ & Very Satisfactory \\
\hline
\end{tabular}


Legend:

\begin{tabular}{llll} 
Scale & Range & \multicolumn{1}{c}{ Remarks } & \multicolumn{1}{c}{ Interpretation } \\
5 & $4.20-5.00$ & $\begin{array}{l}\text { Outstanding } \\
\text { Very }\end{array}$ & Very High \\
2 & $3.40-4.19$ & $\begin{array}{l}\text { High } \\
\text { Satisfactory }\end{array}$ \\
3 & $2.60-3.39$ & Satisfactory & Moderately High \\
2 & $1.80-2.59$ & Fair & Low \\
1 & $1.0-1.79$ & Poor & Very Low
\end{tabular}

The result shows that the ancillary function was high supported by the weighted mean of 4.07. This means that the respondents agreed that the ancillary function they have received are just enough for them to support the main work of the institution.

It was evident in the table that the school acknowledge the influence of community services to promote positive school culture which was supported by the obtained highest weighted mean of 4.24. However, both statements, programs for community services are planned and implemented regularly by the school and community services are performed by teaching staff and personnel as implied with a lowest weighted mean of 3.89. This meant that the academic workloads in terms of Community Services and Linkages is evident.

Community Services and Linkages refers to a non-paying job performed by one person or a group of people for the benefit of their community or its institutions. As such, the Department of Education (2017) provides guidelines that requires different schools to participate in community services and linkages.

In Table 7, the result shows that research was high supported by the weighted mean of 4.12. This means that the respondents agreed that the academic workloads in terms of research they have received are just enough for them to improve the main work of the institution.

It was evident in the table that the research outputs are aligned to the needs of the institution which was supported by the obtained highest weighted mean of 4.24. However, external training and seminars/workshops for research are provided as implied with a lowest weighted mean of 3.98. This meant that the academic workloads in terms of Research is very satisfactory.

Table 7. Mean Level Of Instructional Leaders' Productivity In terms of Research

\begin{tabular}{|c|c|c|}
\hline STATEMENT & Mean & Remarks \\
\hline $\begin{array}{l}\text { 1. External training and seminars/workshops for research are } \\
\text { provided. }\end{array}$ & 3.98 & Very Satisfactory \\
\hline $\begin{array}{l}\text { 2. Research outputs are translated into productive and sound } \\
\text { resource materials for instructions and technology for } \\
\text { community development. }\end{array}$ & 4.09 & Very Satisfactory \\
\hline $\begin{array}{l}\text { 3. Research projects are aligned with the research thrusts and } \\
\text { priorities of the Department of Education. }\end{array}$ & 4.00 & Very Satisfactory \\
\hline $\begin{array}{l}\text { 4. In-house reviews are attended by teachers and involved } \\
\text { individuals. }\end{array}$ & 4.13 & Very Satisfactory \\
\hline $\begin{array}{l}\text { 5. Teachers are aware and conduct research diligently as } \\
\text { required. }\end{array}$ & 4.22 & Outstanding \\
\hline $\begin{array}{l}\text { 6. Research presentation are participated by teachers and } \\
\text { involved individuals. }\end{array}$ & 4.16 & Very Satisfactory \\
\hline 7. Research outputs are aligned to the needs of the institution. & 4.24 & Outstanding \\
\hline Grand Mean & 4.12 & Very Satisfactory \\
\hline Interpretation & & ligh \\
\hline
\end{tabular}

(6) 2021 EPRA IJRD | Journal DOI: https://doi.org/10.36713/epra2016 | www.eprajournals.com |219 
Legend:

\begin{tabular}{llll} 
Scale & Range & Remarks & \multicolumn{1}{c}{ Interpretation } \\
5 & $4.20-5.00$ & Outstanding & Very High \\
2 & $3.40-4.19$ & $\begin{array}{l}\text { Very } \\
\text { Satisfactory }\end{array}$ \\
& & High \\
3 & $2.60-3.39$ & Satisfactory & Moderately High \\
2 & $1.80-2.59$ & Fair & Low \\
1 & $1.0-1.79$ & Poor & Very Low
\end{tabular}

This refers to a non-paying job performed by one person or a group of people for the benefit of their community or its institutions. As such, the Department of Education (2017) provides guidelines that requires different schools to participate in community services and linkages.

Jenkins (2018) noted existing evidence that commitments to teaching and research can be synergistic and complementary or antagonistic and competing. Thus, he argued that the relationships between research, teaching, broader work expectations, and rewards need to be defined and managed at the institutional, departmental, and individual levels to avoid potentially undesirable effects and counterproductive.

Table 8. Mean Level of Instructional Leaders' Productivity In terms of Professional Development

\begin{tabular}{lll}
\hline \multicolumn{1}{c}{ STATEMENT } & Mean & Remarks \\
\hline $\begin{array}{l}\text { 1. Builds valuable work skills and improves individual } \\
\text { performance by increasing knowledge and enhancing } \\
\text { productivity. }\end{array}$ & 4.22 & Very Satisfactory \\
$\begin{array}{l}\text { 2. Provides management and leadership training, seminars, and } \\
\text { conferences to enable collaboration and accelerate change with } \\
\text { school staff, personnel and employ yees. }\end{array}$ & 4.11 & Very Satisfactory \\
$\begin{array}{l}\text { 3. Provides workshops to faculty, school staff, and personnel } \\
\text { with the fundamental skills for applications in the workplace. }\end{array}$ & 4.07 & Very Satisfactory \\
$\begin{array}{l}\text { 4. Encourages the development of researches based on specific } \\
\text { goals of the school for improvement. }\end{array}$ & 3.91 & Very Satisfactory \\
$\begin{array}{l}\text { 5. Provides a wide variety of specialized training intended to } \\
\text { help teachers, improve their professional competence, skill, and } \\
\text { effectiveness. }\end{array}$ & 4.09 & Very Satisfactory \\
$\begin{array}{l}\text { 6. Provides e-learning platforms to improve interpersonal skills } \\
\text { with school staff, personnel and employees. }\end{array}$ & 4.16 & Very Satisfactory \\
$\begin{array}{l}\text { 7. Provides formal education, or advanced professional learning } \\
\text { intended to help teachers improve their professional knowledge } \\
\text { and skills. }\end{array}$ & 4.09 & Very Satisfactory \\
\hline Grand Mean & $\mathbf{4 . 0 9}$ & Very Satisfactory \\
\hline Interpretation & High \\
\hline
\end{tabular}

Legend:

\begin{tabular}{|c|c|c|c|}
\hline Scale & Range & Remarks & Interpretation \\
\hline 5 & $4.20-5.00$ & Outstanding & Very High \\
\hline 2 & $3.40-4.19$ & $\begin{array}{l}\text { Very } \\
\text { Satisfactory }\end{array}$ & High \\
\hline 3 & $2.60-3.39$ & Satisfactory & Moderately High \\
\hline 2 & $1.80-2.59$ & Fair & Low \\
\hline 1 & $1.0-1.79$ & Poor & Very Low \\
\hline
\end{tabular}

(6) 2021 EPRA IJRD | Journal DOI: https://doi.org/10.36713/epra2016 | www.eprajournals.com |220 | 
The result shows that professional development was high supported by the weighted mean of 4.09. This means that the respondents agreed that the instructional leaders' productivity in terms of professional development they have received are just enough for them to improve their qualifications for the institution.

It was evident in the table that the statement builds valuable work skills and improves individual performance by increasing knowledge and enhancing productivity was supported by the obtained highest weighted mean of 4.22. However, encourages the development of researches based on specific goals of the school for improvement as implied with a lowest weighted mean of 3.91. This meant that the Instructional Leaders' Productivity in terms of Professional Development is very satisfactory.

Professional development lies at the core of approximately every educational effort to progress student success. It denotes to the learning to get or sustain qualified credentials such as academic degrees to formal coursework, attending conferences and trainings for improvement (Hawley and Valili, 2017).

Table 9 result shows that awards, recognition and achievement was high supported by the weighted mean of 4.01. This means that the respondents agreed that the instructional leaders' productivity in terms of Awards, Recognition and Achievement they have received are just enough for them to be motivated and continue working happily.

Table 9. Mean Level of Instructional Leaders' Productivity In terms of Awards and Recognition and Achievement

\begin{tabular}{|c|c|c|c|c|c|}
\hline \multicolumn{4}{|c|}{ STATEMENT } & Mean & Remarks \\
\hline \multicolumn{4}{|c|}{ 1. Feel that the school I am working recognize my hard work. } & 4.04 & Very Satisfactory \\
\hline \multicolumn{4}{|c|}{$\begin{array}{l}\text { 2. Receive positive feedbacks that motivate yourself to improve } \\
\text { teaching process. }\end{array}$} & 4.07 & Very Satisfactory \\
\hline \multicolumn{4}{|c|}{ 3. Receive appraisal on how well I work } & 4.09 & Very Satisfactory \\
\hline \multicolumn{4}{|c|}{$\begin{array}{l}\text { 4. Feel acknowledged for the accomplishments that support the } \\
\text { organizations goals and values. }\end{array}$} & 4.07 & Very Satisfactory \\
\hline \multicolumn{4}{|c|}{ 5. Am acquired recognition regularly. } & 3.80 & Very Satisfactory \\
\hline \multicolumn{4}{|c|}{ 6. Am attained awards for exemplary work in school. } & 3.87 & Very Satisfactory \\
\hline \multicolumn{4}{|c|}{$\begin{array}{l}\text { 7. Am given equal opportunities for professional growth and } \\
\text { development. }\end{array}$} & 4.13 & Very Satisfactory \\
\hline \multicolumn{4}{|c|}{$\begin{array}{l}\text { Grand Mean } \\
\end{array}$} & 4.01 & Very Satisfactory \\
\hline \multicolumn{4}{|c|}{ Interpretation } & \multicolumn{2}{|c|}{ High } \\
\hline \multicolumn{6}{|l|}{ Legend: } \\
\hline & $4.20-5.00$ & Outstanding & Very High & & \\
\hline & $3.40-4.19$ & $\begin{array}{l}\text { Very } \\
\text { Satisfactory }\end{array}$ & High & & \\
\hline 3 & $2.60-3.39$ & Satisfactory & Moderately High & & \\
\hline & $1.80-2.59$ & Fair & Low & & \\
\hline & $1.0-1.79$ & Poor & Very Low & & \\
\hline
\end{tabular}

It was evident in the table that they are given equal opportunities for professional growth and development supported by the obtained highest weighted mean of 4.13 . However, although perceived as very satisfactory, the statement that they acquired recognition regularly as implied with a lowest weighted mean of 3.80. This meant that the Instructional Leaders' Productivity in terms of Awards, Recognition and Achievement is very satisfactory.

Recognition is a very rewarding experience for an excellent classroom teacher and his or her students. Recognition for teachers builds off of some of the well-known extrinsic and intrinsic motivational theories. It offers hope for meaningful recognition to the other teachers working to improve student-learning outcomes. It also brings pride and support from the teacher's students, administration, governing board and general public (Andrews, 2017). 


\section{Instructional Leaders' Job Satisfaction}

Instructional Job Satisfaction was determined by the weighted mean and described in terms of work condition, job security, salaries and benefits, working environment, social satisfaction and self-actualization.

Table 10 result shows that work condition was very high supported by the weighted mean of 4.22. This means that the respondents agreed that the instructional leaders' productivity in terms of Work Condition they have received are just enough for them to continue working without compromising the school environment.

It was evident in the table that both statements that gives teachers room to grow by providing different tasks for self- discovery and safe school environment is provided to give feeling of security to teachers and other employees inside the school supported by the obtained highest weighted mean of 4.29. However, although perceived as outstanding, the statement that their boundaries are defined within which teachers can make his or her own decisions and give them freedom to act.as implied with a lowest weighted mean of 4.09. This meant that the Instructional Leaders' Productivity in terms of Work Condition is very high.

Table 10. Mean Level of Instructional Leaders' Job Satisfaction In terms of Work Condition

\begin{tabular}{|c|c|c|c|c|c|}
\hline \multicolumn{4}{|c|}{ STATEMENT } & Mean & Remarks \\
\hline \multicolumn{4}{|c|}{$\begin{array}{l}\text { 1. Boundaries are defined within which teachers can make his or } \\
\text { her own decisions and give them freedom to act. }\end{array}$} & 4.09 & Very Satisfactory \\
\hline \multicolumn{4}{|c|}{$\begin{array}{l}\text { 2. Discovers what teachers do best, find better ways for people } \\
\text { to support each other and bring them together. }\end{array}$} & 4.22 & Outstanding \\
\hline \multicolumn{4}{|c|}{$\begin{array}{l}\text { 3. Gives teachers room to grow by providing different tasks for } \\
\text { self- discovery. }\end{array}$} & 4.29 & Outstanding \\
\hline \multicolumn{4}{|c|}{$\begin{array}{l}\text { 4. Willingness to support each member of the organization } \\
\text { through thick and thin to earn trust and foster remarkable } \\
\text { loyalty and tenacity is evident }\end{array}$} & 4.24 & Outstanding \\
\hline \multicolumn{4}{|c|}{$\begin{array}{l}\text { 5. Gives teachers time to learn, time to experiment, and time to } \\
\text { manage their personal affairs. }\end{array}$} & 4.22 & Outstanding \\
\hline \multicolumn{4}{|c|}{$\begin{array}{l}\text { 6. Positive school culture is evident and experienced in the } \\
\text { school practices. }\end{array}$} & 4.20 & Outstanding \\
\hline \multicolumn{4}{|c|}{$\begin{array}{l}\text { 7. Safe school environment is provided to give feeling of } \\
\text { security to teachers and other employees inside the school. }\end{array}$} & 4.29 & Outstanding \\
\hline \multicolumn{4}{|c|}{$\begin{array}{l}\text { Grand Mean } \\
\end{array}$} & 4.22 & Outstanding \\
\hline \multicolumn{4}{|c|}{ Interpretation } & \multicolumn{2}{|c|}{ Very High } \\
\hline \multicolumn{6}{|l|}{ Legend: } \\
\hline & $\begin{array}{l}\text { Range } \\
4.20-5.00\end{array}$ & $\begin{array}{l}\text { Remarks } \\
\text { Outstanding }\end{array}$ & $\begin{array}{l}\text { Interpretation } \\
\text { Very High }\end{array}$ & & \\
\hline & $3.40-4.19$ & $\begin{array}{l}\text { Very } \\
\text { Satisfactory }\end{array}$ & High & & \\
\hline & $2.60-3.39$ & Satisfactory & Moderately High & & \\
\hline & $1.80-2.59$ & Fair & Low & & \\
\hline & $1.0-1.79$ & Poor & Very Low & & \\
\hline
\end{tabular}

Ohide, A. (2017), stated that the deprived and terrible working conditions are among other factors causative to teachers' levels of job dissatisfaction. The association between teacher incentives and student performance could be due to better schools accepting teacher incentives or to teacher incentives causing more effort from teachers; it is intolerable to rule out the previous explanation with our cross-sectional data. 
SJIF Impact Factor 2021: 8.013| ISI I.F.Value:1.241| Journal DOI: 10.36713/epra2016

ISSN: 2455-7838(Online)

EPRA International Journal of Research and Development (IJRD)

Volume: 6 | Issue: 7 | July 2021

- Peer Reviewed Journal

Table 11. Mean Level of Instructional Leaders' Job Satisfaction in terms of Job Securities, Salaries and Benefits

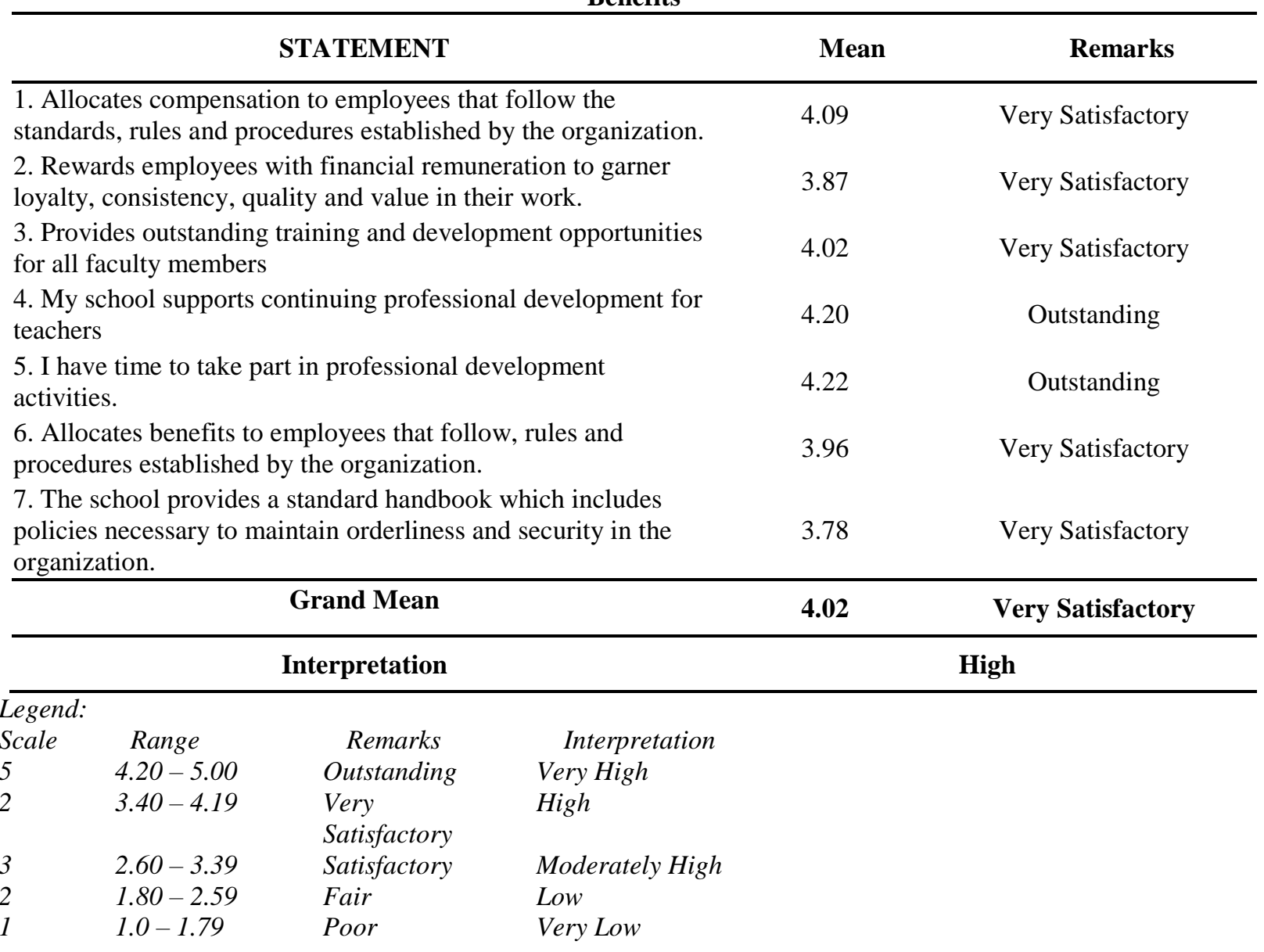

The result shows that Job Securities, Salaries and Benefits was very satisfactory supported by the weighted mean of 4.02. This means that the respondents agreed that the instructional leaders' productivity in terms of Job Securities, Salaries and Benefits they have received are just enough for them to continue working without compromising the school environment.

It was evident in the table that the statement I have time to take part in professional development activities supported by the obtained highest weighted mean of 4.23 perceived as outstanding. However, although perceived as very satisfactory, the statement that the school provides a standard handbook which includes policies necessary to maintain orderliness and security in the organization. as implied with a lowest weighted mean of 3.78 . This meant that the Instructional Leaders' Productivity in terms of Job Securities, Salaries and Benefits is high.

Hanushek and Rivkin, (2017), recently determined that salary affects teacher flexibility patterns less than do working conditions, such as amenities, security, and quality of control.

Table 12 shows the result that Working Environment was very high supported by the weighted mean of 4.14. This means that the respondents agreed that the instructional leaders' productivity in terms of Working Environment that they have received are just enough for them to continue working without compromising the school environment.

It was evident in the table that the statement School facilities are monitored for safety supported by the obtained highest weighted mean of 4.29 perceived as outstanding. However, although perceived as very satisfactory, the statement that Employers take a proactive approach toward equipment safety by identifying facilities that need to be serviced on a regular basis and checked for possible malfunctions as implied with a lowest weighted mean of

(6) 2021 EPRA IJRD | Journal DOI: https://doi.org/10.36713/epra2016 | www.eprajournals.com |223 | 
4.00. This meant that the Instructional Leaders' Productivity in terms of Job working environment is very satisfactory.

Table 12. Mean Level of Instructional Leaders' Job Satisfaction In terms of Working Environment

\begin{tabular}{|c|c|c|}
\hline STATEMENT & Mean & Remarks \\
\hline $\begin{array}{l}\text { 1. The institution encourages a proactive stance toward } \\
\text { preventing injuries. }\end{array}$ & 4.09 & Very Satisfactory \\
\hline $\begin{array}{l}\text { 2. All employees receive adequate training regarding safety } \\
\text { procedures and be able to identify possible hazards. }\end{array}$ & 4.11 & Very Satisfactory \\
\hline $\begin{array}{l}\text { 3. Employees undergo periodic training programs to refresh } \\
\text { their knowledge and skills which may include emergency } \\
\text { preparedness drill }\end{array}$ & 4.11 & Very Satisfactory \\
\hline $\begin{array}{l}\text { 4. Employers take a proactive approach toward equipment } \\
\text { safety by identifying facilities that need to be serviced on a } \\
\text { regular basis and checked for possible malfunctions. }\end{array}$ & 4.00 & Very Satisfactory \\
\hline $\begin{array}{l}\text { 5. Employees and students are provided with well-ventilated } \\
\text { and classrooms conducive for learning. }\end{array}$ & 4.16 & Very Satisfactory \\
\hline 6. School facilities are monitored for safety. & 4.29 & Outstanding \\
\hline $\begin{array}{l}\text { 7. School practice various drills in preparation to certain } \\
\text { hazards. }\end{array}$ & 4.24 & Outstanding \\
\hline Grand Mean & 4.14 & Very Satisfactory \\
\hline Interpretation & \multicolumn{2}{|c|}{ Very High } \\
\hline
\end{tabular}

\section{Legend:}

\begin{tabular}{llll} 
Scale & Range & Remarks & \multicolumn{1}{c}{ Interpretation } \\
5 & $4.20-5.00$ & Outstanding & Very High \\
2 & $3.40-4.19$ & Very & High \\
& & Satisfactory & \\
3 & $2.60-3.39$ & Satisfactory & Moderately High \\
2 & $1.80-2.59$ & Fair & Low \\
1 & $1.0-1.79$ & Poor & Very Low
\end{tabular}

Obineli (2017) contended that stirred workplace would result in inspired workers and lures attention to the status for work performance, the atmosphere, quality and style of buildings and offices. Environment conditions improve working atmosphere.

Table 13. Mean Level of Instructional Leaders' Job Satisfaction In terms of Social Satisfaction

\begin{tabular}{lll}
\hline \multicolumn{1}{c}{ STATEMENT } & Mean & Remarks \\
\hline $\begin{array}{l}\text { 1. Members of the organization recognize and respect each } \\
\text { other's area of expertise and show willingness to compromise on } \\
\text { objectives and process for better results. }\end{array}$ & 4.11 & Very Satisfactory \\
$\begin{array}{l}\text { 2. Mapping out the responsibilities of each members are made } \\
\text { ahead of time to avoid disagreements and disorganization later } \\
\text { on to develop mutual respect for everyone. }\end{array}$ & 4.07 & Very Satisfactory \\
$\begin{array}{l}\text { 3. Each department work collaboratively for the benefits of the } \\
\text { institution }\end{array}$ & 4.18 & Very Satisfactory
\end{tabular}


4. Presence of flattened organizational hierarchy and better communication with all levels of the organization

5. Groups' function on the basis of shared power and management among peers, rather than an absolute directive from the top.

6. Communicate well with each other.

7. Feel welcome and needed in the organization.
$4.11 \quad$ Very Satisfactory

$4.07 \quad$ Very Satisfactory

$4.16 \quad$ Very Satisfactory

$4.20 \quad$ Outstanding

\begin{tabular}{ccc}
\hline Grand Mean & 4.13 & Very Satisfactory \\
\hline Interpretation & & High \\
\hline
\end{tabular}

\section{Legend:}

Scale Range

$5 \quad 4.20-5.00$

$2 \quad 3.40-4.19$

$3 \quad 2.60-3.39$

$2 \quad 1.80-2.59$

$1 \quad 1.0-1.79$

Remarks
Outstanding
Very
Satisfactory
Satisfactory
Fair
Poor

Poor

\section{Interpretation}

Very High

High

Moderately High

Low

Very Low

The result shows that Social Satisfaction was high supported by the weighted mean of 4.13. This means that the respondents agreed that the instructional leaders' productivity in terms of Social Satisfaction that they have received are just enough for them to continue working without compromising the school environment.

It was evident in the table that the statement feels welcome and needed in the organization supported by the obtained highest weighted mean of 4.20 perceived as outstanding. However, although perceived as very satisfactory, both the statement Groups' function on the basis of shared power and management among peers, rather than an absolute directive from the top and Mapping out the responsibilities of each members are made ahead of time to avoid disagreements and disorganization later on to develop mutual respect for everyone as implied with a lowest weighted mean of 4.07. This meant that the Instructional Leaders' Productivity in terms of Social Satisfaction is very satisfactory.

Table 14. Mean Level of Instructional Leaders' Job Satisfaction In terms of Self-Actualization

\begin{tabular}{|c|c|c|}
\hline STATEMENT & Mean & Remarks \\
\hline $\begin{array}{l}\text { 1. Achieve full potential through creativity, independence and } \\
\text { grasp of the real world. }\end{array}$ & 4.04 & Very Satisfactory \\
\hline $\begin{array}{l}\text { 2. Establish oneself as a whole person, able to develop one's } \\
\text { abilities and to understand oneself. }\end{array}$ & 4.09 & Very Satisfactory \\
\hline $\begin{array}{l}\text { 3. Desire to use all their abilities to achieve things that I } \\
\text { possibly can. }\end{array}$ & 4.09 & Very Satisfactory \\
\hline 4. Work hard to grow and reach their full potential. & 4.22 & Outstanding \\
\hline 5. Seek fulfillment and change through personal growth. & 4.22 & Outstanding \\
\hline 6. Have strong moral and ethical values. & 4.22 & Outstanding \\
\hline $\begin{array}{l}\text { 7. Teachers are problem-centered, work hard and take } \\
\text { responsibilities. }\end{array}$ & 4.18 & Very Satisfactory \\
\hline $\begin{array}{ll}\text { Grand Mean } \\
\end{array}$ & 4.15 & Very Satisfactory \\
\hline Interpretation & \multicolumn{2}{|c|}{ High } \\
\hline
\end{tabular}


Legend:

$\begin{array}{llll}\text { Scale } & \text { Range } & \text { Remarks } & \text { Interpretation } \\ 5 & 4.20-5.00 & \text { Outstanding } & \text { Very High } \\ 2 & 3.40-4.19 & \begin{array}{l}\text { Very } \\ \text { Satisfactory }\end{array} & \text { High } \\ 3 & 2.60-3.39 & \text { Satisfactory } & \text { Moderately High } \\ 2 & 1.80-2.59 & \text { Fair } & \text { Low } \\ 1 & 1.0-1.79 & \text { Poor } & \text { Very Low }\end{array}$

The result shows that Self-Actualization was very high supported by the weighted mean of 4.15. This means that the respondents agreed that the instructional leaders' productivity in terms of Self-Actualization that they have received are just enough for them to continue working without compromising the school environment.

It was evident in the table that the statements work hard to grow and reach their full potential, seek fulfillment and change through personal growth and have strong moral and ethical values supported by the obtained highest weighted mean of 4.22 perceived as outstanding. However, although perceived as very satisfactory, the statement that achieve full potential through creativity, independence and grasp of the real world as implied with a lowest weighted mean of 4.04. This meant that the Instructional Leaders' Productivity in terms of Job working environment is very satisfactory.

Effect of Academic workloads to Instructional Leaders' Productivity and Job Satisfaction among Public School Elementary Teachers in Liliw District, Laguna

Minitab 14 was used in computing the data gathered and treated them statistically using Multiple Regression. The computed p-values were compared to the level of significance at 0.05 to determine the significant effect of Academic workloads as to teaching load allocation, working hours, preparation time, coaching and mentoring and ancillary function to Instructional Leaders' Productivity as to community services and linkages, research, professional development and awards and recognition and achievement and to Job Satisfaction as to work condition, job security, salaries and benefits, working environment, social satisfaction and self-actualization.

Table 15. Effect of Academic workloads to Instructional Leaders' Productivity as to Community services and linkages

\begin{tabular}{|c|c|c|c|c|}
\hline Variables & t-value & p-value & Decision on $\mathrm{H}_{\mathrm{o}}$ & Analysis \\
\hline $\begin{array}{l}\text { Teaching load allocation } \\
\text { Community services and } \\
\text { linkages }\end{array}$ & 0.33 & 0.740 & Accept & Not Significant \\
\hline $\begin{array}{l}\text { Working Hours } \\
\text { Community services and } \\
\text { linkages }\end{array}$ & -1.28 & 0.208 & Accept & Not Significant \\
\hline $\begin{array}{l}\text { Preparation Time } \\
\text { Community services and } \\
\text { linkages }\end{array}$ & 3.31 & 0.002 & Reject & Significant \\
\hline $\begin{array}{l}\text { Coaching and Mentoring } \\
\text { Community services and } \\
\text { linkages }\end{array}$ & 0.13 & 0.895 & Accept & Not Significant \\
\hline $\begin{array}{l}\text { Ancillary Function } \\
\text { Community services and } \\
\text { linkages }\end{array}$ & 2.23 & 0.031 & Reject & Significant \\
\hline
\end{tabular}




\section{SJIF Impact Factor 2021: 8.013| ISI I.F.Value:1.241| Journal DOI: 10.36713/epra2016 ISSN: 2455-7838(Online) EPRA International Journal of Research and Development (IJRD) Volume: 6 | Issue: 7 | July 2021

The above result shows the effect of academic workloads as to teaching load allocation, working hours, preparation time, coaching and mentoring and ancillary function to Instructional Leaders' Productivity as to community services and linkages.

It can be seen from the table above that the obtained p-values of $0.740,0.208$ and 0.895 between teaching load allocation, working hours and coaching and mentoring and community services and linkages were respectively higher than the 0.05 level of significance which indicated that the null hypothesis had been accepted. This further implied that academic workloads as to teaching load allocation, working hours, coaching and mentoring has no significant effect on instructional leader's community services and linkages productivity. This means that the respondents' academic workload may not hinder them to be productive in doing community services.

However, the $\mathrm{p}$ values of 0.002 and 0.031 between preparation time and ancillary function were accordingly lower than the 0.05 level of significance which indicated that the null hypothesis had been rejected. This further implied that academic workloads as to preparation time and ancillary function has a significant effect on instructional leader's community services and linkages productivity. This means that the respondents' community services and linkages productivity depend on the preparation time allocated and the additional tasks to be done.

Table 16. Effect of Academic workloads to Instructional Leaders' Productivity as to Research

\begin{tabular}{lcccc}
\hline \multicolumn{1}{c}{ Variables } & t-value & p-value & Decision on $\mathrm{H}_{\mathrm{o}}$ & Analysis \\
\hline $\begin{array}{l}\text { Teaching load allocation } \\
\text { Research }\end{array}$ & 0.38 & 0.703 & Accept & Not Significant \\
\hline $\begin{array}{l}\text { Working Hours } \\
\text { Research }\end{array}$ & 0.31 & 0.761 & Accept & Not Significant \\
\hline $\begin{array}{l}\text { Preparation Time } \\
\text { Research }\end{array}$ & 0.81 & 0.421 & Accept & Not Significant \\
\hline $\begin{array}{l}\text { Coaching and Mentoring } \\
\text { Research }\end{array}$ & -0.58 & 0.562 & Accept & Not Significant \\
\hline $\begin{array}{l}\text { Ancillary Function } \\
\text { Research }\end{array}$ & 2.24 & 0.031 & Reject & Significant \\
* significant at .05 level of significance & & &
\end{tabular}

The above result shows the effect of academic workloads as to teaching load allocation, working hours, preparation time, coaching and mentoring and ancillary function to Instructional Leaders' Productivity as to Research.

It can be seen from the table above that the obtained p-values of $0.703,0.761,0.421$ and 0.562 between teaching load allocation, working hours, preparation time and coaching and mentoring as to research were respectively higher than the 0.05 level of significance which indicated that the null hypothesis had been accepted. This further implied that academic workloads as to teaching load allocation, working hours, coaching and mentoring has no significant effect on instructional leader's productivity as to research. This means that the respondents' academic workload may not hinder them to be productive in doing research.

However, the $\mathrm{p}$ values of 0.031 and ancillary function were accordingly lower than the 0.05 level of significance which indicated that the null hypothesis had been rejected. This further implied that academic workloads as to ancillary function has a significant effect on instructional leader's research productivity. This means that the respondents' research productivity depend on the additional tasks to be done. 
SJIF Impact Factor 2021: 8.013| ISI I.F.Value:1.241| Journal DOI: 10.36713/epra2016

ISSN: 2455-7838(Online)

EPRA International Journal of Research and Development (IJRD)

Volume: 6 | Issue: 7 | July 2021

- Peer Reviewed Journal

Table 17. Effect of Academic workloads to Instructional Leaders' Productivity as to Professional Development

\begin{tabular}{lcccc}
\hline \multicolumn{1}{c}{ Variables } & t-value & p-value & Decision on $\mathrm{H}_{\mathrm{o}}$ & Analysis \\
\hline $\begin{array}{l}\text { Teaching load allocation } \\
\text { Professional Development }\end{array}$ & 0.82 & 0.419 & Accept & Not Significant \\
\hline $\begin{array}{l}\text { Working Hours } \\
\text { Professional Development }\end{array}$ & -1.17 & 0.227 & Accept & Not Significant \\
\hline $\begin{array}{l}\text { Preparation Time } \\
\text { Professional Development }\end{array}$ & 2.47 & 0.018 & Reject & Significant \\
\hline $\begin{array}{l}\text { Coaching and Mentoring } \\
\text { Professional Development }\end{array}$ & 2.01 & 0.051 & Accept & Not Significant \\
\hline $\begin{array}{l}\text { Ancillary Function } \\
\text { Professional Development }\end{array}$ & 2.90 & 0.006 & Reject & Significant \\
\hline
\end{tabular}

*significant at .05 level of significance

The above result shows the effect of academic workloads as to teaching load allocation, working hours, preparation time, coaching and mentoring and ancillary function to Instructional Leaders' Productivity as to Professional Development.

It can be seen from the table above that the obtained p-values of $0.419,0.227$ and 0.051 between teaching load allocation, working hours and coaching and mentoring as to professional development were respectively higher than the 0.05 level of significance which indicated that the null hypothesis had been accepted. This further implied that academic workloads as to teaching load allocation, working hours, coaching and mentoring has no significant effect on instructional leader's productivity as to research. This means that the respondents' academic workload may not hinder them to be productive in professional development.

However, the $\mathrm{p}$ values of 0.018 and 0.006 between preparation time and ancillary function were accordingly lower than the 0.05 level of significance which indicated that the null hypothesis had been rejected. This further implied that academic workloads as to preparation time and ancillary function has a significant effect on instructional leader's professional development. This means that the respondents' professional development depends on the preparation time allocated and the additional tasks to be done.

Table 18. Effect of Academic workloads to Instructional Leaders' Productivity as to Awards and Recognition

\begin{tabular}{lcccc}
\hline \multicolumn{1}{c}{ Variables } & t-value & p-value & Decision on $\mathrm{H}_{\mathrm{o}}$ & Analysis \\
\hline $\begin{array}{l}\text { Teaching load allocation } \\
\text { Awards and Recognition }\end{array}$ & 0.54 & 0.595 & Accept & Not Significant \\
\hline $\begin{array}{l}\text { Working Hours } \\
\text { Awards and Recognition }\end{array}$ & 0.60 & 0.551 & Accept & Not Significant \\
\hline $\begin{array}{l}\text { Preparation Time } \\
\text { Awards and Recognition }\end{array}$ & 1.18 & 0.245 & Accept & Not Significant \\
\hline $\begin{array}{l}\text { Coaching and Mentoring } \\
\text { Awards and Recognition }\end{array}$ & -0.05 & 0.962 & Accept & Not Significant \\
\hline $\begin{array}{l}\text { Ancillary Function } \\
\text { Awards and Recognition }\end{array}$ & 0.36 & 0.722 & Accept & Not Significant \\
\hline
\end{tabular}

*significant at .05 level of significance

(6) 2021 EPRA IJRD | Journal DOI: https://doi.org/10.36713/epra2016 | www.eprajournals.com |228 | 
The above result shows the effect of academic workloads as to teaching load allocation, working hours, preparation time, coaching and mentoring and ancillary function to Instructional Leaders' Productivity as to Awards and Recognition.

It can be seen from the table above that the obtained p-values of $0.595,0.551,0.245,0.962$ and 0.722 between teaching load allocation, working hours, preparation time, ancillary function and coaching and mentoring as to Awards and Recognition were respectively higher than the 0.05 level of significance which indicated that the null hypothesis had been accepted. This further implied that academic workloads as to teaching load allocation, preparation time, ancillary function, working hours, coaching and mentoring has no significant effect on instructional leader's productivity as to awards and recognition. This means that the respondents' academic workload may not hinder them to be productive in awards and recognition.

Effect of Academic workloads to Instructional Leaders' Job Satisfaction

Table 19. Effect of Academic workloads to Instructional Leaders' Job Satisfaction as to Work Condition

\begin{tabular}{lcccc}
\hline \multicolumn{1}{c}{ Variables } & t-value & p-value & Decision on $\mathrm{H}_{\mathrm{o}}$ & Analysis \\
\hline $\begin{array}{l}\text { Teaching load allocation } \\
\text { Work Condition }\end{array}$ & 0.38 & 0.706 & Accept & Not Significant \\
\hline $\begin{array}{l}\text { Working Hours } \\
\text { Work Condition }\end{array}$ & -0.65 & 0.522 & Accept & Not Significant \\
\hline $\begin{array}{l}\text { Preparation Time } \\
\text { Work Condition }\end{array}$ & 2.44 & 0.019 & Reject & Significant \\
\hline $\begin{array}{l}\text { Coaching and Mentoring } \\
\text { Work Condition }\end{array}$ & 0.50 & 0.619 & Accept & Not Significant \\
\hline $\begin{array}{l}\text { Ancillary Function } \\
\text { Work Condition }\end{array}$ & 1.53 & 0.134 & Accept & Not Significant \\
\hline
\end{tabular}

*significant at .05 level of significance

The result shows the effect of academic workloads as to teaching load allocation, working hours, preparation time, coaching and mentoring and ancillary function to Instructional Leaders' Productivity as to Work Condition.

It can be seen from the table above that the obtained p-values of $0.706,0.522,0.0 .619$ and 0.134 between teaching load allocation, working hours, ancillary function and coaching and mentoring as to Work Condition were respectively higher than the 0.05 level of significance which indicated that the null hypothesis had been accepted. This further implied that academic workloads as to teaching load allocation, preparation time, ancillary function, working hours, coaching and mentoring has no significant effect on instructional leader's job satisfaction as to work condition. This means that the respondents' academic workload may not hinder them to be productive under work condition.

However, the $p$ value 0.019 of preparation time was accordingly lower than the 0.05 level of significance which indicated that the null hypothesis had been rejected. This further implied that academic workloads as to preparation time has a significant effect on instructional leader's work condition. This means that the respondents' work condition depends on the preparation time allocated and the additional tasks to be done. 
SJIF Impact Factor 2021: 8.013| ISI I.F.Value:1.241| Journal DOI: 10.36713/epra2016

ISSN: 2455-7838(Online)

EPRA International Journal of Research and Development (IJRD)

Volume: 6 | Issue: 7 | July 2021

- Peer Reviewed Journal

Table 20. Effect of Academic workloads to Instructional Leaders' Job Satisfaction as to Job Security, Salaries and Benefits

\begin{tabular}{|c|c|c|c|c|}
\hline Variables & t-value & p-value & Decision on $\mathrm{H}_{\mathrm{o}}$ & Analysis \\
\hline $\begin{array}{l}\text { Teaching load allocation } \\
\text { Job Security, Salaries and } \\
\text { Benefits }\end{array}$ & 0.65 & 0.517 & Accept & Not Significant \\
\hline $\begin{array}{l}\text { Working Hours } \\
\text { Job Security, Salaries and } \\
\text { Benefits }\end{array}$ & 0.53 & 0.601 & Accept & Not Significant \\
\hline $\begin{array}{l}\text { Preparation Time } \\
\text { Job Security, Salaries and } \\
\text { Benefits }\end{array}$ & 0.21 & 0.837 & Accept & Not Significant \\
\hline $\begin{array}{l}\text { Coaching and Mentoring } \\
\text { Job Security, Salaries and } \\
\text { Benefits }\end{array}$ & -0.29 & 0.771 & Accept & Not Significant \\
\hline $\begin{array}{l}\text { Ancillary Function } \\
\text { Job Security, Salaries and } \\
\text { Benefits }\end{array}$ & 2.63 & 0.012 & Reject & Significant \\
\hline
\end{tabular}

*significant at .05 level of significance

The above result shows the effect of academic workloads to Instructional Leaders; Job Satisfaction as to Job Security, Salaries and Benefits as to teaching load allocation, working hours, preparation time, coaching and mentoring and ancillary function to Instructional Leaders' Job Satisfaction as to Job Security, Salaries and Benefits.

It can be seen from the table above that the obtained p-values of $0.517,0.601,0.0 .837$ and 0.771 between teaching load allocation, working hours, preparation time and coaching and mentoring as to Job Security, Salaries and Benefits were respectively higher than the 0.05 level of significance which indicated that the null hypothesis had been accepted. This further implied that academic workloads as to teaching load allocation, preparation time, working hours, coaching and mentoring has no significant effect on instructional leader's job satisfaction as to work condition. This means that the respondents' academic workload may not hinder them to be productive under work condition.

However, it was evident that the Job security, Salaries and Benefits as to Ancillary Function is rejected as per the Null Hypothesis with a p-value of 0.012. This is because the ancillary function was found to be significant in terms of Instructional Leader's Job Satisfaction.

Table 21 shows the effect of academic workloads as to teaching load allocation, working hours, preparation time, coaching and mentoring and ancillary function to Instructional Leaders' Job Satisfaction as to Working Environment.

It can be seen from the table above that the obtained p-values of $0.231,0.725,0.0 .097,0.744$ and 0.134 between teaching load allocation, working hours, preparation time, coaching and mentoring and ancillary function as to working environment were respectively higher than the 0.05 level of significance which indicated that the null hypothesis had been accepted. This further implied that academic workloads as to teaching load allocation, preparation time, ancillary function, working hours, coaching and mentoring has no significant effect on instructional leader's job satisfaction as to working environment. This means that the respondents' academic workload may not hinder them to be productive under working environment. 
SJIF Impact Factor 2021: 8.013| ISI I.F.Value:1.241| Journal DOI: 10.36713/epra2016

ISSN: 2455-7838(Online)

EPRA International Journal of Research and Development (IJRD)

Volume: 6 | Issue: 7 | July 2021

- Peer Reviewed Journal

Table 21. Effect of Academic workloads to Instructional Leaders' Job Satisfaction as to Working

Environment

\begin{tabular}{lcccc}
\hline \multicolumn{1}{c}{ Variables } & t-value & p-value & Decision on $\mathrm{H}_{\mathrm{o}}$ & Analysis \\
\hline $\begin{array}{l}\text { Teaching load allocation } \\
\text { Working Environment }\end{array}$ & 1.22 & 0.231 & Accept & Not Significant \\
\hline $\begin{array}{l}\text { Working Hours } \\
\text { Working Environment }\end{array}$ & 0.35 & 0.725 & Accept & Not Significant \\
\hline $\begin{array}{l}\text { Preparation Time } \\
\text { Working Environment }\end{array}$ & 1.70 & 0.097 & Accept & Not Significant \\
\hline $\begin{array}{l}\text { Coaching and Mentoring } \\
\text { Working Environment }\end{array}$ & 0.33 & 0.744 & Accept & Not Significant \\
\hline $\begin{array}{l}\text { Ancillary Function } \\
\text { Working Environment }\end{array}$ & 0.75 & 0.455 & Accept & Not Significant \\
\hline
\end{tabular}

*significant at .05 level of significance

Table 22. Effect of Academic workloads to Instructional Leaders' Job Satisfaction as to Social Satisfaction

\begin{tabular}{lcccc}
\multicolumn{1}{c}{ Variables } & t-value & p-value & Decision on $\mathrm{H}_{\mathrm{o}}$ & Analysis \\
\hline $\begin{array}{l}\text { Teaching load allocation } \\
\text { Social Satisfaction }\end{array}$ & 0.12 & 0.906 & Accept & Not Significant \\
\hline $\begin{array}{l}\text { Working Hours } \\
\text { Social Satisfaction }\end{array}$ & -0.13 & 0.895 & Accept & Not Significant \\
\hline $\begin{array}{l}\text { Preparation Time } \\
\text { Social Satisfaction }\end{array}$ & 2.05 & 0.047 & Reject & Significant \\
\hline $\begin{array}{l}\text { Coaching and Mentoring } \\
\text { Social Satisfaction }\end{array}$ & 1.09 & 0.283 & Accept & Not Significant \\
\hline $\begin{array}{l}\text { Ancillary Function } \\
\text { Social Satisfaction }\end{array}$ & 1.36 & 0.183 & Accept & Not Significant \\
\hline
\end{tabular}

*significant at .05 level of significance

The above result shows the effect of academic workloads as to teaching load allocation, working hours, preparation time, coaching and mentoring and ancillary function to Instructional Leaders' Job Satisfaction as to Work Condition.

It can be seen from the table above that the obtained p-values of $0.906,0.895,0.283$ and 0.183 between teaching load allocation, working hours, coaching and mentoring and ancillary function as to Social Satisfaction were respectively higher than the 0.05 level of significance which indicated that the null hypothesis had been accepted. This further implied that academic workloads as to teaching load allocation, working hours, coaching and mentoring and ancillary function has no significant effect on instructional leader's job satisfaction as to Social Satisfaction. This means that the respondents' academic workload may not hinder them to be productive under Social Satisfaction.

However, it was evident that the Instructional Leader's Job Satisfaction as to Social Satisfaction with regards to Preparation time is rejected as per the Null Hypothesis with a p-value of 0.047. This is because the Preparation Time was found to be significant in terms of Instructional Leader's Job Satisfaction. 
SJIF Impact Factor 2021: 8.013| ISI I.F.Value:1.241| Journal DOI: 10.36713/epra2016

ISSN: 2455-7838(Online)

EPRA International Journal of Research and Development (IJRD)

Volume: 6 | Issue: 7 | July 2021

- Peer Reviewed Journal

Table 23. Effect of Academic workloads to Instructional Leaders' Job Satisfaction as to Self-Actualization

\begin{tabular}{lcccc}
\multicolumn{1}{c}{ Variables } & t-value & p-value & Decision on $\mathrm{H}_{\mathrm{o}}$ & Analysis \\
\hline $\begin{array}{l}\text { Teaching load allocation } \\
\text { Self-Actualization }\end{array}$ & 1.36 & 0.181 & Accept & Not Significant \\
\hline $\begin{array}{l}\text { Working Hours } \\
\text { Self-Actualization }\end{array}$ & 0.09 & 0.929 & Accept & Not Significant \\
\hline $\begin{array}{l}\text { Preparation Time } \\
\text { Self-Actualization }\end{array}$ & 1.33 & 0.191 & Accept & Not Significant \\
\hline $\begin{array}{l}\text { Coaching and Mentoring } \\
\text { Self-Actualization }\end{array}$ & 0.94 & 0.355 & Accept & Not Significant \\
\hline $\begin{array}{l}\text { Ancillary Function } \\
\text { Self-Actualization }\end{array}$ & 1.22 & 0.228 & Accept & Not Significant \\
\hline
\end{tabular}

*significant at .05 level of significance

The above result shows the effect of academic workloads as to teaching load allocation, working hours, preparation time, coaching and mentoring and ancillary function to to Instructional Leaders' Job Satisfaction as to Self-Actualization.

It can be seen from the table above that the obtained p-values of $0.181,0.0 .929,0.0191,0.355$ and 0.228 between teaching load allocation, working hours, preparation time, coaching and mentoring, and ancillary function as to Self-Actualization were respectively higher than the 0.05 level of significance which indicated that the null hypothesis had been accepted. This further implied that academic workloads as to teaching load allocation, preparation time, ancillary function, working hours, coaching and mentoring has no significant effect on instructional leader's job satisfaction as to self-actualization. This means that the respondents' academic workloads may not hinder them to be productive under Self-Actualization.

\section{CONCLUSION}

Based on the gathered data, the significant relationship between academic workloads as to instructional leaders' productivity and job satisfaction is partially accepted the null hypothesis of which states that "The instructional leaders' profile, academic workload have no significant effect on the teachers' productivity and job satisfaction among public school elementary teachers in Liliw District, Laguna."

\section{RECOMMENDATIONS}

Based on the drawn conclusions resulted to the following recommendations:

1. To rebalance the workload on a regular basis, it may be recommended that automating faculty workload to ensure faculties in institutions optimally spend their time and align with the interests of the institution to maximize efficiency and effectiveness in all areas of operations. Faculty workload management system can help administrators to determine how best to divide the work.

2. Creating an action plan based on evaluation scores to enable faculty members to attend workshops, courses and conferences that promote the development of skills for both teaching and research can also be an option for the Academic Workloads of teachers to be improved.

3. Furthermore, this research could also be used in other institutions to perceive how Academic Workloads affect Instructional Leaders' Job Satisfaction and Productivity. A larger population would allow for a better generalization of the data.

4. Finally, feedbacks received should be take into consideration to determine the progress of the researchers in achieving their objectives. Shifting the study's focus to interventions that rely on proactive approaches to resolve the issues will be a great follow-up for this study. 


\section{SJIF Impact Factor 2021: 8.013| ISI I.F.Value:1.241| Journal DOI: 10.36713/epra2016 ISSN: 2455-7838(Online) EPRA International Journal of Research and Development (IJRD) Volume: 6 | Issue: 7 | July 2021 - Peer Reviewed Journal}

\section{BIBLIOGRAPHY}

\section{A. Articles and Journals}

1. Andrews, H. (2016), Supporting Quality Teaching with Recognition, Olney Central College, Olney, Illinois, U.S.A., Australian Journal of Teacher Education, Volume 36 | Issue 12

2. Badri, M.A., (2016), A two-stage multi-objective scheduling model for [faculty-course-time] assignments. European Journal of Operational Research 94, 16-28.

3. Baxter, B. (2016) TEACHER PARTICIPATION IN THE COMMUNITY, Pi Lambda Theta Journal Vol. 28, No. 4,

4. Bai, D.Y.; Hu, Z.; Li, M.Q (2017). Discussion on the Task Driven Method in the Teaching of Automation Technology and Application. Stud. Lit. Lang. 2016, 11, 57-61.

5. Bialopotocki, R. (2016), Recognition and praise relate to teachers' job satisfaction

6. Booth, A L.; Van Ours, C. (2016): Part-time jobs: what women want? In: Journal of Population Economics, 26(1), p. 263-283.

7. Breslaw, J.A., (2016) A linear programming solution to the faculty assignment problem. Socioeconomic Planning Services 10, 227-230.

8. Schniederjans, M.J., and Kim, G.C., (2016), A goal programming model to optimize departmental preference in course assignments. Computers \& Operations Research 14, 87-96.

9. Brewer, D. J. (2016). Career paths and quit decisions: Evidence from teaching. Journal of Labor Economics, 14(2), 313-339. doi:https://doi.org/10.1086/209813

10. Capel, S. (2017) Managing Yourself and your Workload Bottom of Form.

11. Chen, H.; Lin, R.; Li, X. (2016) Discussion on the Classroom Teaching Model of Task-Driven and Education Combined with Research in Computer Programming Courses. In Proceedings of the International Symposium on Social Science (ISSS 2016), Wuhan, China, 29-30 August 2016; pp. 258-261.

12. Chowdhury, M. (2019, September 3). What is Coping Theory? Retrieved from PositivePsychology.com website: https://positivepsychology.com/coping-theory/

13. Collins et al. (2016) Teachers' Characteristics and their Attitudes Towards Classroom Management. Calabar: Nigerian Rapid Educational Publishers, Nigeria.

14. Dignath, C. C., \& Buttner, G. (2017). Assessing how teachers enhance self-regulated learning (ATES)-Development of an observation instrument for the primary and secondary school classroom. Manuscript submitted for publication.

15. Don, A. G., Puteh, A., Nasir, B. M., Ashaari, M. F., \& Kawangit, R. M. (2016). The level of understanding and appreciation of Islam among Orang Asli new Muslims in Selangor State, Malaysia and its relationship with social wellbeing. International Journal of Humanities, Arts and Social Sciences, 2(6), 215-220. doi: https://doi.org/10.20469/ijhss.2.20004-6

16. Durlak, J. A., Weissberg, R. P., Dymnicki, A. B., Taylor, R. D., \& Schellinger, K. B. (2016). The impact of enhancing students' social and emotional learning: A meta-analysis of school-based universal interventions. Child Development,

17. Eduese, E. D. 2017. "Teachers: The Issue of Quality, Quantity and Cost in Nigerian Secondary Schools." The Nigerian Principal: Journal of ANCOOPS, 4(2): 32-34

18. Esguerra, D.J. (2018). DepED urged to lighten teacher workloads following suicide reports. Philippine Daily Inquirer. August 27. https://newsinfo.inquirer .net/1025288/deped-urged-to-lighten-teacher -workloads-following-suicidereports (accessed on October 2, 2018).

19. Futernick, K. (2016). A possible dream: Retaining California teachers so all students learn. Sacramento: California State University.

20. Ghee, Y. (2014). Examining Faculty Workload as Antecedent of Job Satisfaction among Academic Staff of Higher Public Education in Kelantan, Malaysia

21. Grempes, G., (2018) Untold stories of teachers with multiple ancillary functions: A phenomenology of fortitude Into, $P$. 2 1, 2 University of Mindanao, Davao, Philippines

22. Harris, D. \& Sass T. (2016) Teacher Training, Teacher Quality, and Student Achievement

23. Halpert, M. (2016). Factors that influence the satisfaction levels of teachers in urban school districts, Doctoral Dissertation, Arizona State University.

24. Hanane, T. (2016). The Effects of Lesson Plan on Teacher's Classroom Management Case study: Second Year English Students of LMD at Biskra University

25. Hanushek, E. \& Rivkin, S. (2017). Pay, working conditions, and teacher quality. The Future of Children, 17(1), 69-86.

26. Hart, A. W. (2016). Work feature values of today's and tomorrow's teachers: Work redesign as an incentive and school improvement policy. Educational Evaluation and Policy Analysis, 16(4), 458-473. doi: https://doi.org/10.2307/1164369

27. Hawley, W.D., \& Valli, L. (2017). The essentials of effective professional development: A new consensus. In G. Sykes \& L. Darling-Hammond (Eds.), Handbook of teaching and policy. New York: Teachers College 
28. Heck, D. (2016). Studying the Effects of Professional Development: The case of the NSF's Local Systematic Change Through Teacher Enhancement Initiative, Journal for Research in Mathematics Education, 2011, Vol. 39, No. 2, pp. $112-252$

29. Heckman \& Masterov, (2016). A study of preservice educators' dispositions to change behavior management strategies. Preventing School Failure, 56, 129-136. doi:10.1080/10459 88X.2011.606440

30. Herzberg, W., et.al (2017), Motivation to work. New York: John Wiley\& Sons.

31. Holly, S; Mohnen, Al. (2016): Impact of working hours on work-life balance. SOEPpapers No. 465. DIW Berlin.

32. Horta, H., (2016). Global and national prominent universities: internationalization, competitiveness and the role of the state. Higher Education 58, 387-405

33. Horta, H., Dautel, V., and Veloso, F.M., (2016). An output perspective on the teaching/research nexus: an analysis focusing on the United States higher education system. Studies in Higher Education 37, 171-187.

34. Javier, E.R. and Deligero, J.C.L. (2016) Job Satisfaction of the Teaching and Non-Teaching Staff of the Lyceum of the Philippines University-Batangas. International Journal of Information, Business and Management, 6, 1-10. https://search.proquest.com/docview/1552838173? accountid $=149218$

35. Lloyd, C., B. Mensch and W. Clark. 2016. "The Effects of Primary School Quality on School Dropout Among Kenyan Girls and Boys." Comparative Education Review, 44(2): 113-147.

36. Kalaw, J.F. (2016) Organizational Culture among Teaching Employees of Lyceum of the Philippines UniversityBatangas: Basis of Enhancement. International Journal of Information, Business and Management, 6, 52-66.

37. Mangaleswarasharma, R., (2017). Teacher Motivation and Job Satisfaction: A Study on Teachers in Three Districts in Northern Sri Lanka, Department of Secondary and Tertiary Education, Faculty of Education, Open University of Sri Lanka, Nawala, Nugegoda, Sri Lanka.

38. Martin, T. N. (2016). Predictors of turnover for inbound and outbound employees. Telemarketing Magazine, 10(10), 60-64.

39. Mateo, J. (2018). DepED probes teacher suicides. The Philippine Star. August 30. https://www.philstar.com/othersections/education-and-home/2018/08/30/1846977/deped-probes-teacher-suicides (accessed on October 2, 2018).

40. Meador, D. (2019) Strategies for Teachers: The Power of Preparation and Planning.

41. Morrison K. (2018) Self-regulated learning and academic achievement: theoretical perspectives (2nd ed.). Mahwah: Erlbaum.

42. Nasser, F., (2016). Socialization of new teachers: Does induction matter? Teaching and Teacher Education, Volume 26, Issue 8, November 2010, Pages 1592-1597

43. Odanga, S. (2016), Influence of Marital Status on Teachers' Self-Efficacy in Secondary Schools of Kisumu County, Kenya, Jaramogi Oginga Odinga University of Science and Technology, Academic Journal of Interdisciplinary Studies, Vol 4 No 3, November 2016

44. Odell, S (2017). Teacher Mentoring and Teacher Retention, https://doi.org/10.1177/0022487192043003006

45. Ohide, A. (2017), Impact of Working Conditions on Teacher's Job Satisfaction and Performance in the Private Primary Schools in Yei Town, South Sudan.

46. Okonkwo, C and Obineli, A. (2016). The Roles of Counselling in Promoting Good Leadership: Anambra State on the Focus. A journal that cuts across all behavioral issues. Vol. 3 (No. 2).

47. Olivero, G., Bane, K.D. and Kopolmen, R.E. (2017), Executive coaching as a transfer of training tool: Effects on productivity in a public agency, Public Personal Management, 26

48. Oswald, Andrew J.; Proto, Eugenio; Sgroi, Daniel (2016): Happiness and productivity. In: Journal of Labor Economics, 33(4), p. 789-822.

49. Ou, X. (2016) Teaching load allocation in a teaching unit: optimizing equity and quality, 25th Annual Conference of the Australasian Association for Engineering Education

50. Paul, A. (2017). The benefits and impacts of a coaching and mentoring program for teaching staff in secondary school, International Journal of Evidence Based Coaching and Mentoring Vol. 5, No.2, August 2013, Page 14

51. Paris \& Paris (2017). Temperamental task orientation: Relation to high school and college educational accomplishments

52. Peters, J., \& Pearce, J. (2016). Relationships and early career teacher resilience: A role for school principals. Teachers and Teaching, 18(2), 249-262. doi: https://doi.org/10.1080/13540602.2012.632266

53. Pearson, L. C., Carroll, D., \& Hall, B. W. (2016). Analysis of demographic, perceptual, and work-related factors in teacher moonlighting. The Journal of Educational Research, 87(5), 304-308. doi: https://doi.org/10.1080/00220671.1994.9941258

54. Punjab, A. (2016). Impact of Qualification and Marital Status on The Professional Attitude of Women Teachers Education, International Journal of Advanced Research in Education \& Technology (IJARET), Vol. 3, Issue 2 (April June 2016) 
55. Shabbir, M. (2019). JOB SATISFACTION STATUS OF PUBLIC PRIMARY SCHOOL TEACHERS: A CASE OF PAKISTAN ADMINISTRATIVE KASHMIR, School of Public Affairs, University of Science and Technology of China, Hefei, Anhui, P.R C, European Journal of Educational Sciences December 2014 edition Vol.1, No.4

56. Shann, M. (2016), Professional commitment and satisfaction among teachers in urban middle schools. The Journal of Educational Research, 92 (2), 67-073

57. Su, Y.S.; Yang, J.H.; Hwang, W.Y.; Huang, S.J.; Tern, M.Y. (2016), Investigating the Role of Computer-Supported Annotation in Problem Solving based Teaching: An Empirical Study of a Scratch Programming Pedagogy. Br. J. Educ. Technol. 2014, 45, 647-665.

58. Thum, Y., (2018) Paying for high-and low-quality teaching Milken Family Foundation,1 250 4th Street, Santa Monica, CA 90401, USA, Economics of Education Review 23 (2004) 411-430

59. Wafula, A. N. (2016). Work-family conflict among women from a collectivistic culture. Department of Industrial Psychology, University of the Western Cape.

60. Wanger, S. (2017) What makes employees satisfied with their working time? The role of working hours, timesovereignty and working conditions for working time and job satisfaction

61. Wijetunge, M. T. N. (2016). Using communicative task-based speaking activities to enhance ESL speaking motivation in undergraduates. International Journal of Humanities, Arts and Social Sciences, 2(6), 203-208. doi: https://doi.org/ 10.20469/ijhss.2.20002-6

62. Zainuddin et al. (2016), Research Methodology for Business \& Social Science. University, Publication Centre (UPENA), UiTM.

63. Zembylas, P. (2016). Sources of job satisfaction and dissatisfaction in Cyprus. British Association for International and Comparative Education, 36(2), 229-247.

64. Zimmerman, B. J., \& Schunk, D. H. (Eds.). (2016). Self-regulated learning and academic achievement: theoretical perspectives (2nd ed.). Mahwah: Erlbaum.

65. Adeyemo, K.S., Sehoole, C. and Cueno, C.G. (2016) The Use of the Job Enrichment Technique for Decision-Making in Higher Education: The Case of the Philippines. SA Journal of Human Resource Management, 13, a645.

66. Carmona (2017) The Effects of Professional Development on Science Teaching Practices and Classroom Culture Consortium for Policy Research in Education, University of Pennsylvania, JOURNAL OF RESEARCH IN SCIENCE TEACHING VOL. 37, NO. 9, PP. $963 \pm 980$ (2000)

67. Dela Cruz, J. (2017), Honor your teachers. National Association of Elementary School Principals. Retrieved from http://www.nbpts.org/ContentLoad.do? contentld=1145.

68. Delgado, L. (2018). 4 Types of Learning Styles: How to Accommodate a Diverse Group of Students | Rasmussen College. Retrieved from Rasmussen.edu website: https://www.rasmussen.edu/degrees/education/blog/types-of-learningstyles/

69. Gregeorio S. (2016) Extension Is Not Just Service, But Service Learning Is Important to Extension, Philippine Cooperative Extension

70. Guidote, A. (2018), Educational Attainment, Teaching Experience, Professional Development and Self-Efficacy as Predictors of Chemistry Content Knowledge: Implication for the Development of a National Promotion Examination, Ateneo de Manila University, 10.26534/kimika.v29i2.7-22

71. Javier, E.R. and Deligero, J.C.L. (2016) Job Satisfaction of the Teaching and Non-Teaching Staff of the Lyceum of the Philippines University-Batangas. International Journal of Information, Business and Management, 6, 1-10. https://search.proquest.com/docview/1552838173? accountid $=149218$

72. Kalaw, J.F. (2016) Organizational Culture among Teaching Employees of Lyceum of the Philippines UniversityBatangas: Basis of Enhancement. International Journal of Information, Business and Management, 6, 52-66.

73. Labadia, D. (2016). Organizational Commitment, Work Performance and Job Satisfaction Among the Faculty of the Religious of Virgin Mary (RVM) Schools in Southern Mindanao. Doctoral Dissertation, "Notre Dame University, Cotabato City".

74. Langguyuan Kadtong, M. (2017).Teaching Performance and Job Satisfaction Among Teachers at Region XII Proceedings Journal of Education, Psychology and Social Science Research, Volume 4, Issue 1, 2017, Mindanao State University.

75. Montemayor, N. (2017). Learning Styles. Retrieved from Vanderbilt University website: https://cft.vanderbilt.edu/guides-sub-pages/learning-styles-preferences/

76. Navarra, M.L (2017). Teaching effectiveness, research productivity, and extension performance in selected state colleges in the Philippines, Philippines Univ., Los Banos, College, Laguna.

77. Sarmiento (2018), "School teachers' job satisfaction and personal characteristics: A quantitative research study in Davao City", International Journal of Educational Management, Vol. 29 No. 1, pp. 73-97. https://doi.org/10.1108/IJEM-05-2013-0081 


\section{SJIF Impact Factor 2021: 8.013| ISI I.F.Value:1.241| Journal DOI: 10.36713/epra2016 ISSN: 2455-7838(Online) EPRA International Journal of Research and Development (IJRD) \\ Volume: 6 | Issue: 7 | July 2021 \\ - Peer Reviewed Journal}

78. Pilarta, M. (2016). Job Satisfaction and Teachers Performance in Abra State Institute of Sciences and Technology, Abra State Institute of Sciences and Technology, Philippines Global Journal of Management and Business Research: Administration and Management, Volume 15 Issue 4 Version 1.0 Year 2016

\section{B. Published/Unpublished Materials}

1. Adhiambo, P. (2017). Examining factors influencing teachers' level of job satisfaction in public primary schools in Kayole Division, Nairobi County. Unpublished Thesis, University of Nairobi.

2. Akiri, A. \& Ugborugbo, N. (2018) An Examination of Gender's Influence on Teachers' Productivity in Secondary Schools, Department of Educational Administration and Policy Studies, Delta State University, Abraka, Delta State, Nigeria.

3. Baker, J. K. (2016). The impact of attachment style on coping strategies, identity development and the perception of social support (Unpublished master's thesis). University of Canterbury, Christchurch, New Zealand.

4. Bijwaard, Govert; van Dijk, Bram; de Koning, Jaap (2016): Working time preferences, labor market transitions and job satisfaction. In: Muffels, Ruud J. A. (ed.): Flexibility and employment security in Europe. In: Labor markets in transition. Cheltenham: Elgar, p. 255-277.

5. Bucheli, M; Melgar, N; Rossi, M and Smith, T (2016). Job satisfaction and the individual educational level, reassessing their relationship. Center for Advanced Study Fellow, University of Illinois, Illinois, USA.

6. David, N. (2016), Individual Teacher Incentives and Student Performance; National Bureau of Economic Research 1050 Massachusetts Avenue Cambridge, MA 02138 October 2008

7. Ehing, D. (2016): Unter- und Überbeschäftigung in Deutschland: Eine Analyse der Arbeitszeitwünsche von Erwerbstätigen vor dem Hintergrund des demografischen Wandels. In: Zeitschrift für Sozialreform, 60(3), p. $247-272$.

8. Ekanem, E. (2016). Beginning teacher educators' development and faculty workload management of Universities in Cross River State of Nigeria, University of Calabar

9. Greubel, Jana; Arlinghaus, Anna; Nachreiner, Friedhelm; Lombardi, David A. (2016): Higher risks when working unusual times? A cross-validation of the effects on safety, health, and work-life balance. In: International archives of occupational and environmental health, 89(8), p. 1205-1214

10. Gurbuz, A. (2016). An Assessment on The Effect of Education Levelon The Job Satisfaction from The Teaching Sector Point of View, Zonguldak Karaelmas University, Safranbolu Vocational School of Higher Education

11. Harris, (D.) (2017), Teacher Training, Teacher Quality and Student Achievement, Department of Educational Policy Studies Department of Economics University of Wisconsin

12. Jenkins, A. (2018). A Guide to the research evidence on teaching-research relations, The Higher Education Academy. Retrieved December 16, 2014,

13. Mbogo, G. (2017). The Influence of Work Environment on Job Satisfaction Among Teachers in Public Primary Schools Programmes In Nembure Division, Embu West District, Kenya

14. Mading, M. (2018). The root causes of teacher attrition (teacher dropout) in the conflict affected South Sudan, Central Equatorial State: Case Study of Gerang Memorial schools.

15. Nginah, M. N. (2016). Influence of work-family conflicts on secondary school

16. teachers' level of job satisfaction in Machakos District, Kenya. Unpublished Thesis. Department of Educational Administration, University of Nairobi.

17. Njoka, E. (2017). Guiding and Counselling Pupils in Kenyan Public Primary Schools: Head Teachers and Teacher Counsellors Role Perceptions and Experiences. Published Doctoral Thesis. Durham University.

18. Obineli, A (2017). Teachers' Perception of the Factors Affecting Job Satisfaction in Ekwusigo Local Government of Anambra State. Department of Guidance and Counselling Nnamdi Azikiwe, University, Awka Anambra State, Nigeria.

19. Rocchi, M. (2017), The contribution of extracurricular coaching on high school teachers' job satisfaction, Pages 305 324 | Received 29 Sep 2016, Accepted 20 Sep 2017, Published online: 10 Oct 2017

20. Singh, S. (2016). Simple Random Sampling. Advanced Sampling Theory with Applications, 71-136. https://doi.org/10.1007/978-94-007-0789-4_2

21. Short, P. M., \& Greer, J. T. (2016). Leadership in empowered schools: Themes from innovative efforts (2nd ed.). Washington, DC, WA: ERIC.

22. Tatar, A. (2020, February). (PDF) Impact of Job Satisfaction on Organizational Commitment. Retrieved from ResearchGate website: https://www.researchgate.net/publication/339401568_Impact_of_Job_Satisfaction_on_Organizational_Commitment

23. The National Academic Press. (2017). Read "Enhancing Organizational Performance" at NAP.edu. In www.nap.edu. Retrieved from https://www.nap.edu/read/5128/chapter/3

24. Tymms, P. (2016). "Teacher Gender has no Effect on Pupil Performance." Retrieved July 27, 2006 from http://www.teachers org.uk.

25. Ulriksen, J., (2018). Perceptions of Secondary School Teachers and Principals Concerning Factors Related to Job Satisfaction and Job Dissatisfaction, 100p.; Ed. D Dissertation, University of Southern California 
SJIF Impact Factor 2021: 8.013| ISI I.F.Value:1.241| Journal DOI: 10.36713/epra2016

ISSN: 2455-7838(Online)

EPRA International Journal of Research and Development (IJRD)

Volume: 6 | Issue: 7 | July 2021

- Peer Reviewed Journal

26. Usop, A. (2018), The Significant Relationship Between Work Performance and Job satisfaction In Philippines, School of Social Sciences, University Saints, Malaysia, Pulau Pinang, Malaysia, International Journal of Human Resource Management and Research, ISSN 2249-6874Vol. 3, Issue 2, Jun 2013, 9-16.

C. Books

27. Berry, L.M. (2016). Psychology at work: an introduction to industrial and organizational psychology, (2nd ed.). Boston, McGraw-Hill.

D. Internet Sources

28. Sherrington, T. (2018) Teachers' workload: tips on how to manage it and get a work-life balance, https://www.theguardian.com/teacher-network/teacher-blog/2013/apr/08/teacher-workload-tips-manage-work-lifebalance

29. Weissman, R. (2016). Global Management by Stress, Multinational Monitor, Jul/Aug 2016, Vol. 22, Issue 7/8. 